\title{
The Impact of Corporate Culture on Marketing Performance
}

\author{
Muhammad Anwar Fathoni \\ Universitas Pembangunan Nasional (UPN) Veteran Jakarta \\ fathoni_e@yahoo.co.id \\ Ahmad Rodoni \\ Universitas Islam Negeri (UIN) Syarif Hidayatullah Jakarta \\ doni_ahmad@yahoo.com
}

Keywords:

Corporate Culture,

Marketing

Performance, Islamic

Banking
ABSTRACT

The purpose of this study is to determine the typology of corporate culture of Islamic banking. This study also aims to determine the influence of corporate culture of Islamic banking on marketing performance.

This study proves that the corporate culture of Islamic banking that accommodates the Islamic teaching has influence on marketing performance. This study is a comparative study between Bank Muamalat and BNI Syariah. Mixed method is used in this study to analyze collected data. The primary data obtained through survey and interview with employees of the Islamic bank. While secondary data obtained from the annual report documentation, books and articles in scientific journals and other sources that relevant to the research. 


\section{A. INTRODUCTION}

Marketing is one of the most important elements in the company, and the success of the company's business depends on the implementation of its marketing strategy (Kotler and Armstrong, 2012). The marketing paradigm has grown since the last 60 years that has led to a change in the marketing orientation from product-centric to consumer-centric to human-centric (Kotler et al., 2010). In marketing studies, corporate culture is defined as a set of fundamental beliefs and values that place customers in the company's thinking about their business strategies and practices. Although corporate culture has a central role in marketing management, few of the experts are examining the impact of corporate culture on marketing (Deshpande and Webster, 1989).

There are two focuses of marketing research that incorporate culture as one of its perspectives, namely consumer culture and corporate culture. In the perspective of consumer culture, several studies (Luna and Gupta, 2001; Acar et al., 2011; Antunes, 2013) conclude that consumer culture can influence the company in determining its marketing strategy. In addition, it was found a close relationship among corporate values (shared values), corporate behavior and productivity (Berson et al., 2008; Slater et al., 2011). However, the values that underlie corporate culture are still a debate to date. The values used are mostly derived from empirical research and their experience in running a company's business (Sutrisno, 2010). Marketing activities involving religion are considered ineffective in attracting customers (Kamarulzaman and Madun, 2013). On the other hand, Muslim scholars conclude otherwise. Religiusity assessed can give influence to company performance. (Usman et al., 2017; Kashif et al., 2017).

The Islamic banking industry is becoming the center of the business world today. Islamic banks are claimed to be different from conventional banks in the context of a business model with a profit sharing system used by both banks (profit sharing vs interest) (Hassan et al., 2008). Another distinctive feature of Islamic banking is the Islamic values that are made into the corporate soul (Kartajaya and Sula, 2006).

Since the existence of various forms of Indonesian government regulations on Islamic Banking, the growth of Islamic banking industry in Indonesia is significant. As of 
December 2016, Islamic banks have a network of 13 Islamic Commercial Banks (BUS), 22 Islamic Business Units (UUS), and 165 Islamic Rural Banks (BPRS) (www.ojk.go.id). However, in the context of marketing performance, the market share of Islamic banks in Indonesia is still relatively low compared to conventional banks. Until the end of 2016, the market share of new Islamic banks reached 5.3\% (www.ojk.go.id). This proves that the competitiveness and attractiveness of Islamic banks is still not optimal. In fact, the religiosity of Islamic banking is often questionable because it seems to focus only on maximizing profits. (Usman et al., 2017).

The point of view of the Islamic bank's corporate culture becomes interesting to be studied in the context of its influence on marketing performance. The central role of corporate culture in marketing studies and still the lack of marketing management experts who examine the relationship of Islamic corporate culture to marketing performance become the main motivation the authors conducted this study.

\section{B. LITERATUR REVIEW}

\section{Corporate Culture}

The term corporate culture here refers to organizational culture. Deshpande and Webster define organizational culture as a pattern of shared values and beliefs used to understand the functioning of organizations, serve as the norms held in behaving in their organizations (Deshpande and Webster, 1989). Furthermore, Schein states that organizational culture is a pattern of basic assumptions that a group has learned to overcome external and internal problems, which are applicable and followed by members, and taught to new members as a code of conduct and solving organizational problems (Schein, 2004). From the two definitions, it is concluded that corporate culture is a set of values, beliefs, assumptions, or norms that are enacted, agreed and followed by employees of a company as a code of conduct and problem solving company.

Organizational culture has two different levels seen in terms of their clarity and resilience to change (Kotter, 1997). At a more visible level, culture reflects the pattern of the norms/ behaviors of an organization that cause new employees to be automatically compelled to follow. The way people dress, how they talk to each other, how the interior of the office is arranged 
in such a way, is a visible part of the corporate culture. At a deeper and less visible level, culture refers to values that shared by group members and tends to persist even if members change. (Deshpandé et al., 1993).

There are several concepts that can be used to know the culture of a company. Geert Hofstede for example proposed 5 cultural attributes that can be used to analyze corporate culture and consumer culture, namely power distance, individualism/ collectivism, masculinity/femininity, uncertainty avoidance, and long-/short-term orientation (Mooij and Hofstade, 2011). Edgar H. Schein in this case also offers a quite different concept of organizational culture. Schein states there are 3 levels of organizational culture, namely artifacts, beliefs and values and underlying assumptions.

The other concept of corporate culture is offered by Kim S. Cameron and Robert E. Quinn. They created an assessment instrument they called the Organizational Culture Assessment Instrument (OCAI) to identify the corporate culture. The assessment instrument is based on a theoretical framework called The Competing Values Framework. The theoretical framework is based on 6 attributes of organizational culture, namely dominant characteristics, organizational leadership, management of employees, organization glue, strategic emphases, and criteria of success. With identification using OCAI, the profile of organizational culture can be classified into 4 types, namely clan, hierarchy, adhocracy, and market (Cameron and Quinn, 2006).

Clan. This type of organizational culture is characterized by intimate relationships and family systems. A growing leadership style is usually more likely to be a conflict facilitator or an existing problem in the organization. The effectiveness criteria are emphasized on team cohesiveness, employee morale development and human resources. Management guidelines are principled on the importance of employee participation or members of the organization. This type of organizational culture can be developed under certain conditions, such as the organization's long history, member stability, and the interrelationships of individuals within the organization $(\mathrm{Yu}$ and $\mathrm{Wu}, 2009)$.

Hierarchy. This type of organizational culture is characterized by a more rigid, formal and well-structured work 
environment. All work processes are regulated in a standard and systematic manner. This culture is relevant to the bureaucratic environment. The leadership style developed is as a coordinator with strong and strict mentoring functions, as well as a superior organizer. The management guidelines used center on tight control and control. Formal rules become a unifying element in the organization. This type of cultural focus is on internal maintenance by promoting organizational stability and full organizational leadership (Simberova, 2009).

Adhocracy. This type of organizational culture is characterized by a work environment not restricted by the structure, because this type of culture is more concerned with the creation of situations where employees or members of the organization can freely explore and channel creative and innovative ideas. Leadership styles are developed more as innovators, entrepreneurs, and visionary leadership. The effectiveness criteria focuses on clear output, effective work processes and sustainable development. The culture of adhocracy is often found in industries such as filmmaking and software development (Microsoft, Google, Yahoo, and so on).

Market. This type of organizational culture is characterized by an orientation to the results. The leadership style developed is as a competitor, and a strong driver. The effectiveness criteria focus on how to beat competitors and achieve targets. Management guidance used is the principle of competition in achieving productivity. Deshpandé said that this type of culture focuses on competitive advantage and market advantage. Its focus on external maintenance with regard to organizational stability and control (Deshpandé et al., 1993).

\section{Marketing Performance}

The marketing paradigm has changed over time. Marketing is defined as the process of moving products (goods or services) from the hands of producers to the hands of consumers. Marketing is a social and managerial process used by individuals and groups to get what they need and want by creating, offering, and freely exchanging value products with others (Kotler, 1997).

The marketing concept is dominated by the marketing mix. The marketing mix is a set of marketing tools with customer oriented, consisting of marketing variables that can be 
controlled, used by marketers to achieve marketing objectives or targeted target market. The concept of marketing mix has 4 elements known as The Four Ps: Product, Price, Place, Promotion (Borden, 1984; Goi, 2009).

The dominance of marketing mix then shifted by the concept of relationship marketing and emotional marketing. This concept consists of 4 elements that are abbreviated as 4Es, namely emotion, exclusivity, engengement, and experience (Sutrisno, 2010). The next development came from Philip Kotler. He said there has been a shift in marketing orientation and now there is a change that leads to human-centric, which is called the term Marketing 3.0. This marketing concept considers three aspects at once, namely functional, emotional, and spiritual values (Kotler et al., 2010). The development of Islamic economics in recent decades has contributed to the concept of marketing in an Islamic perspective. Marketing that involves the turning of goods and services must be based on norms and ethics so as to avoid cheating, carelessness, and injustice (Rahman, 2014).

Islamic marketing basically also adopts the concept of modern marketing. Conceptually, there is almost no difference between the concept of modern marketing and the concept of Islamic marketing. However, Islamic marketing is more focused on the values and norms of a series of marketing activities (Ahmad et al, 2014). The role of Islam in the study of marketing is as a marketing tool (Arham, 2010). The values derived from Islamic teachings are integrated with existing marketing theories with a normative approach based on the Qur'an and Hadith (alTahir and Murad, 2013).

One indicator of the success of a company's performance is its marketing performance. Marketing performance is a measure of achievement that achieved from the overall marketing activities of a company. Marketing performance is also used as a measure of the extent to which market achievements have been achieved by a product that produced by the company. Marketing metrics is one measure of the results of marketing activities or commonly also called marketing performance.

The purpose of marketing metrics is basically to measure the performance of marketing in running strategy that has been established company. Measurement of marketing performance can be done qualitatively and quantitatively. Qualitative measurement generally relates to a person's perceptions or 
attitudes about one type of marketing activity the company undertakes. While quantitative measurement involves more figures obtained from the company's marketing activities (Astami, 2016).

Marketing metrics can be classified into two groups, namely financial metrics and non-financial metrics. Financial metrics can be calculated in the form of the amount of money used, such as the ratio of profitability (return on equity/ROE and return on investment/ROI). While non-financial metrics cannot be calculated in the form of money, but can be measured with other forms of money, such as market share, consumer behavior, innovation, and consumer satisfaction (Solcansky et al., 2011).

Cristian Homburg and Christian Pflesser in his research used 7 indicators to measure marketing performance. Research conducted on 5 different industries in Germany uses both types of indicators, namely financial indicators and non-financial indicators. The financial indicator used is Return on Sales, while the non-financial indicators are customer satisfaction, value of customers, current customer, new customer, growth of company, and market share (Homburg and Pflesser, 2015). Astami used 3 indicators to measure marketing performance, which is total marketing cost, product profitability, and return on sales (Astami, 2016).

In this study, the hypothesis to be tested is as follows:

H1: The corporate culture that accommodate Islamic teaching has a significant effect on marketing performance.

$\mathrm{H} 0$ : The corporate culture that accommodate Islamic teaching does not have a significant effect on marketing performance.

\section{EMPIRICAL}

This research is a descriptive research with mixed methods analysis method, that is analysis which combine quantitative and qualitative method. (Creswell, 2009). This study also uses the comparative method used to compare the corporate culture and marketing performance of Bank Muamalat with BNI Syariah.

The data used are primary data and secondary data. Primary data in this study was obtained through questionnaires and interviews. Respondents in this study were employees of Bank Muamalat KC Arthaloka Central Jakarta and BNI Syariah 
KC Depok West Java which amounted to 60 people. The selection of the two sharia banks is based on recommendations from Bank Muamalat Pusat and BNI Syariah Pusat. In-depth interviews were also conducted on the Consumer Sales Head of both sharia banks, as well as some informants relevant to the research.

The data obtained is then processed using the Sequential Explanatory Strategy strategy in mixed methods, which is by presenting quantitative data analysis at the beginning first, then presented qualitative data analysis in the next section to strengthen the result of quantitativedata analysis (Creswell,2009). This strategy is used to see the corporate culture typology and marketing performance of the two sharia banks studied. In this study, simple regression analysis is used to see the relationship between corporate culture and marketing performance, as well as independent test samples test used to compile the marketing performance of the two sharia banks studied.

\section{RESULT AND DISCUSSION}

\section{Portrait of Corporate Culture of Bank Muamalat and BNI Syariah}

To identify the corporate culture typology of Bank Muamalat and BNI Syariah, the authors use the organizational culture assessment instrument of Cameron and Quinn, called the Organizational Culture Assessment Instrument (OCAI). The results of the data on the corporate culture of Bank Muamalat and BNI Syariah can be seen from the following 6 cultural attributes:

Table 1

Attribute Percentage of Dominant Character

\begin{tabular}{|c|l|c|c|c|c|}
\hline $\begin{array}{c}\text { Cultural } \\
\text { Attributes }\end{array}$ & \multicolumn{1}{|c|}{ Bank } & Clan & Adhocracy & Market & Hierarchy \\
\hline \multirow{2}{*}{$\begin{array}{l}\text { Dominant } \\
\text { characteristics }\end{array}$} & $\begin{array}{l}\text { Bank } \\
\text { Muamalat }\end{array}$ & $\mathbf{8 5 \%}$ & $65 \%$ & $75 \%$ & $81 \%$ \\
\cline { 2 - 6 } & BNI Syariah & $\mathbf{8 6 \%}$ & $68 \%$ & $80 \%$ & $84 \%$ \\
\hline \multirow{2}{*}{$\begin{array}{l}\text { Organizational } \\
\text { leadership }\end{array}$} & $\begin{array}{l}\text { Bank } \\
\text { Muamalat }\end{array}$ & $70 \%$ & $54 \%$ & $\mathbf{7 8 \%}$ & $77 \%$ \\
\cline { 2 - 6 } & BNI Syariah & $74 \%$ & $69 \%$ & $66 \%$ & $\mathbf{7 7 \%}$ \\
\hline
\end{tabular}




\begin{tabular}{|l|l|c|c|c|c|}
\hline \multirow{2}{*}{$\begin{array}{l}\text { Management } \\
\text { of employees }\end{array}$} & $\begin{array}{l}\text { Bank } \\
\text { Muamalat }\end{array}$ & $\mathbf{8 1 \%}$ & $56 \%$ & $66 \%$ & $78 \%$ \\
\cline { 2 - 6 } & BNI Syariah & $\mathbf{8 5 \%}$ & $69 \%$ & $71 \%$ & $77 \%$ \\
\hline \multirow{2}{*}{$\begin{array}{l}\text { Organization } \\
\text { glue }\end{array}$} & $\begin{array}{l}\text { Bank } \\
\text { Muamalat }\end{array}$ & $\mathbf{7 3 \%}$ & $62 \%$ & $72 \%$ & $71 \%$ \\
\cline { 2 - 6 } & BNI Syariah & $\mathbf{8 6 \%}$ & $73 \%$ & $75 \%$ & $77 \%$ \\
\hline \multirow{2}{*}{$\begin{array}{l}\text { Strategic } \\
\text { emphases }\end{array}$} & $\begin{array}{l}\text { Bank } \\
\text { Muamalat }\end{array}$ & $75 \%$ & $65 \%$ & $78 \%$ & $\mathbf{8 1 \%}$ \\
\cline { 2 - 6 } & BNI Syariah & $75 \%$ & $74 \%$ & $\mathbf{8 1 \%}$ & $80 \%$ \\
\hline \multirow{2}{*}{$\begin{array}{l}\text { Criteria of } \\
\text { success }\end{array}$} & $\begin{array}{l}\text { Bank } \\
\text { Muamalat }\end{array}$ & $\mathbf{8 2 \%}$ & $69 \%$ & $78 \%$ & $73 \%$ \\
\cline { 2 - 6 } & BNI Syariah & $79 \%$ & $75 \%$ & $\mathbf{8 4 \%}$ & $81 \%$ \\
\hline
\end{tabular}

Source: Primary data, 2016

The dominant character attributes of Bank Muamalat and BNI Syariah are both more inclined to the clan culture type with consecutive values of $85 \%$ and $86 \%$. These findings indicate that members of the organization within the company make Bank Muamalat and BNI Syariah as a forum that unites each member with good interpersonal relationships, mutual trust and caring among members. The basic assumption in clan culture is the strength of teamwork and HR employee development in creating a humanist work environment (Cameron and Quinn, 2006). Culture of this clan basically in accordance with the character of the Indonesian nation is known as a friendly and humanist nation and mutual cooperation in the community.

To build a culture of cooperation among individuals, there are several activities that become routine corporate programs such as morning briefing in every Monday morning by Bank Muamalat, even BNI Syariah do it every day in the morning. In this case, BNI Syariah also specifies the principle of cooperation in its value semantics. One of the semantic values of BNISyariah is the value of jama' ah or togetherness (Muladsih and Siregar, 2016). In Islam is known as ta'awun term, that is help each other human (QS Al-Maidah verse 2). Ta'awun is an effort to help each other to lighten the burden borne by others so that the burden becomes light or lost (Surat al-Baqarah verse 177). This aid can be either material or in other forms, such as energy and mind.

The leadership culture of Bank Muamalat appear to be more examples of market culture with a value of $78 \%$, while BNI Syariah is more inclined towards hierarchy culture with a value 
of $77 \%$. It can be concluded that competitive and challenging culture to win the market and expand market share from the leadership is visibly perceived by current employees of Bank Muamalat. The existence of targets to be achieved, especially by marketers of Bank Muamalat make them challenged to work extra to gain achievement. Unfortunately, the spirit of competing in winning the market in Bank Muamalat has not been well controlled. There are still many marketers of Bank Muamalat who "light handed" receive the financing proposal from customers for the achievement of the target leader. As a result, Bank Muamalat must bear high financing costs. This can be proven from the high number of non-performance financing of Bank Muamalat, which is 7.11\% in 2015 (Fitrachman, 2016).

The hierarchy culture in BNISyariah leadership attributes is more aggressive and has considerable attention to personal control. This style of lead is more open to conflict and criticism. Decision-making emerges from the process of argumentation with multiple points of view, resulting in decisions that satisfy all parties (Camerond and Quinn, 2006). The career path determines the existing leadership in BNI Syariah. Although from different backgrounds, every leader in BNI Syariah must follow the values set by the company, namely amanah and jama'ah (Siregar, 2016). The distinguishing concept of Islamic leadership and conventional leadership lies in religiosity and morality. The religious spirit of a leader is characterized by the principle of tauhid attached to him (al-Anbiya verse 73). While the moral spirit is characterized by the attitude of trust, that is honest and dare to be responsible for all his actions (Ahmad and Ongansula, 2011). Islamic leadership has its own characteristics, which is transformational, ethical and authentic leadership, not leadership with transactional style (Galanou and Farrag, 2015).

The employee management attributes of Bank Muamalat and BNI Syariah are seen to be more inclined to clan culture with sequence of $81 \%$ and $85 \%$. It indicates that the management of employees in both Islamic bank is dominated by the culture of cooperation among its employees to achieve the common goal. Teamwork and participation of employees of Bank Muamalat and BNI Syariah can be seen in the planning process until the implementation of business. For both Islamic bank, every employee is marketer and every marketer must participate and be responsible for the company's reputation and sustainability. Every employee is required to behave in accordance with 
the value expected by the company (value adopted), namely upholding the moral values and aqidah in accordance with Islam for Bank Muamalat and the value of amanah and jama'ah for BNI Syariah.

The authors found that the both of Islamic bank held a spiritual activity involving all employees in the face of business dealings or the launch of new products and services. Bank Muamalat chose to hold a tahajud prayer together, while BNI Syariah prefer to hold Khatm al-Qur'an. Oktavia Rattika Muladsih exemplifies, when Bank Muamalat will launch a new system that has never been used before, Bank Muamalat management do tahajud together. This activity is important to be undertaken as part of Bank Muamalat's management effort for the successful launch of the new system (Muladsih and Siregar, 2016). These various spiritual activities show that the both of Islamic bank have been managing Islamic resources based on tauhid, world-oriented hereafter and have the motivation to pursue the pleasure of Allah SWT. (Usman et al, 2015). Orientation on material values, human values, good values and spiritual values must be embedded in all employees in order to run the business with the world-oriented hereafter (Yusanto, 2002).

The organization glue attributes of Bank Muamalat and BNI Syariah are also seen to be more inclined to clan culture with $73 \%$ and $86 \%$ respectively. In clan culture, the glue among employees in the company is loyalty and mutual trust (Camerond and Quinn, 2006). Loyalty and mutual trust can grow from honesty and open communication among employees. The attitude of honesty and open communication has been instilled by the company to all employees of Bank Muamalat. Although it is not included in the semantics of its value, but honesty is considered as the main capital in teamwork (Muladsih, 2016). BNI Syariah incorporates an attitude of honesty in the semantics of its value, namely Amanah. That is, every employee is required to be honest and keep the promise. In addition, every employee is required to always be responsible for his work, work sincerely and prioritize the intention of worship, and serve beyond expectations (Siregar, 2016). Islam commands mankind to be honest, because honesty is the main capital of the unity of the ummah. Another advantage of honest behavior is to gain good value in the sight of Allah. (Surah Al-Ahzab verses 70-71, Surah Al-Isra verse 53). In a corporate context, it takes solid team work 
to achieve optimal performance. And honesty is the key to team solidity in working.

The corporate orientation attributes of Bank Muamalat seem to be more inclined to a cultural hierarchy of $81 \%$. These findings suggest that current orientation of Bank Muamalat emphasizes the importance of sustainability by taking measures of efficiency and tight control. The financial condition of Bank Muamalat in recent years has been the main reason for changing its business perspective. In 2014, Bank Muamalat made a change in the composition of the directors that led to changes in its direction and business perspective. There is a new division that specializes in the assets of Bank Mualamat, namely Special Asset Management division. It is specifically tasked to evaluate and maintain the quality of assets owned by Bank Muamalat. This change is a real step taken to overcome the declining financial condition experienced by Bank Muamalat (Fitrachman, 2016).

On the other hand, the orientation of BNI Syariah is more inclined to market culture with value of $81 \%$. It shows that the company emphasizes the importance of competitive actions of its employees. The spirit of the competition becomes the driving force for achievement. The employees are required to provide the best possible service to their customers because the main orientation of the company is to reach the target and win the market competition. A strong desire to win the national banking market can be seen from its semantic vision, which is "Becoming a Superior Islamic Bank of Choice in Service and Performance" (Siregar, 2016).

The success criteria attributes of Bank Muamalat look more inclined to the clan culture with a value of $82 \%$. Bank Muamalat sees success measured by competence of Human Resources (HR) that can work together (teamwork), have a commitment together, and have concern for others. This is evidenced by the establishment of the Muamalat Institute in 1999 focusing on the development of Human Resources (Muladsih, 2016). However, according to the author's opinion, there is inconsistency in its development of human resources. It should be able to guide excellent cadres in running its financial business with the existence of special institutions that focus in the development of human resources. But, its financial condition is very fluctuating, even tended to experience slowing growth in the last 5 years, as well as the increasing number of 
Non-Performing Financing (NPF) which is one of the causes is a looseness in providing financing, indicating its inconsistency that focus in developing human resources.

In contrast to Bank Muamalat, the success criteria of BNI Syariah companies are more inclined to market culture. The company's success assessment is based on winning the market. The motivation given by the company to the employees is how to provide optimal services for their network network. The vision of BNI Syariah is in line with this finding, which is "Becoming a Superior Islamic Bank of Excellence in Service and Performance" (Siregar, 2016). The motivation to be a winner in the financial market must be controlled by the various spiritual activities undertaken together. Internalization of values embraced through spiritual activities becomes invisible (invisible hands) for employees to work as closely as possible in order to reach the market as possible, but to remain in control of the work ethic of Islam (Ismaeel and Blaim, 2012).

Table 2

Comparative Cultural Attributes of Bank Muamalat and BNI Syariah

\begin{tabular}{|l|c|c|}
\hline \multicolumn{1}{|c|}{ Cultural Attributes } & Bank Mualamat & Bni Syariah \\
\hline Dominant characteristics & Clan & Clan \\
\hline Organizational leadership & Market & Hierarchy \\
\hline Management of employees & Clan & Clan \\
\hline Organization glue & Clan & Clan \\
\hline Strategic emphases & Hierarchy & Market \\
\hline Criteria of success & Clan & Market \\
\hline
\end{tabular}

Source: Primary data, 2016

From the table above, it can be concluded that the corporate culture of Bank Muamalat and BNI Syariah basically are dominated by clan culture type, although there are differences in some cultural attributes. The corporate culture of both Islamic bank also has characteristics with Islamic values, ethics and symbols. Spirituality present in corporate values which is then actualized into daily behavior can have a positive impact on employee performance (Beikzad, Chaharborj, Maleki, 2012; Bakri, 2015). The values, ethics and symbols of Islam are as follows: 
a. The semantic of value owned and applied by BNI Syariah is Amanah and Jamaah. The value of Amanah is manifested in an honest attitude and keeping promises, being responsible, eager to give the best work, to work sincerely and to prioritize the intention of worship, and to serve beyond expectation (QS al-Baqarah verse 282 - 283, Surah al-Anfal verse 27, QS al-Mukminun verses 8 and 11, Surah alAhzab verse 73, and QS al-Ma' arij verses 32 and 35). While Jamaah values are embodied in a caring and courageous attitude of giving and accepting constructive criticism and suggestions, building synergies professionally, sharing useful knowledge, understanding the linkages of work processes, and strengthening effective leadership (Surah alMaidah verse 2) (Fauzia, 2013).

b. One of the most visible cultural elements of the corporate culture of Bank Muamalat and BNI Syariah is the ethics of speaking in greeting each of its customers, by always say "salam". The use of language that characterizes Islam is one of the keys to the success of marketing of Islamic banks (Ahmed, Ullah, Alam, 2014).

c. Obligation to close aurat, especially for women that must wear hijab (Surah An-Nur verse 31). Bank Muamalat and BNI Syariah require all female employees to wear hijab. Hijab is part of the symbol of Islam. Wearing religious clothes is an important expression of one's religious identity. It reflects the understanding of the wearer of the requirements set out in their traditions or beliefs that wearing such clothing as a sign of religious commitment and helping to improve their spiritual life (Naser and Tamam, 2012).

d. Various religious activities such as praying $d z u h u r$ togather, regular recitation and even ritual tahajjud together to succeed business and marketing. From the results of interviews and observations that the author did, praying $d z u h u r$ togather has become a daily routine conducted by all employees, both at Bank Muamalat and BNI Syariah. In fact, every branch office of Bank Muamalat and BNI Syariah have mushalla used for religious activity. When the time of praying dzuhur have been entered, the employees stopped their activities and immediately went to the mushalla to perform the dzuhur prayers in congregation. The employees of Bank Muamalat and BNI Syariah also invite customers to 
join dzuhur prayers in congregation (Muladsih and Siregar, 2016).

\section{Marketing Performance of Bank Muamalat and BNI Syariah}

Before presenting the marketing performance of Bank Muamalat and BNI Syariah during the last 5 years (2012-2016), the authors will present the result of independent sample test in order to know whether there is difference statistically the two data are compared:

Table 3

Independent Samples Test

\begin{tabular}{|c|c|c|c|c|c|c|c|}
\hline & \multicolumn{2}{|c|}{$\begin{array}{l}\text { Levene's } \\
\text { Test for } \\
\text { Equality } \\
\quad \text { of } \\
\text { Variances }\end{array}$} & \multicolumn{5}{|c|}{ t-test for Equality of Means } \\
\hline & $\mathbf{F}$ & Sig. & $\mathbf{T}$ & df & $\begin{array}{c}\text { Sig. } \\
\text { (2-tailed) }\end{array}$ & $\begin{array}{c}\text { Mean } \\
\text { Difference }\end{array}$ & $\begin{array}{l}\text { Std. Error } \\
\text { Difference }\end{array}$ \\
\hline \multirow{2}{*}{$\begin{array}{l}\text { Market } \\
\text { share }\end{array}$} & .668 & .445 & 15.329 & 6 & .000 & 15.16250 & .98917 \\
\hline & & & 15.329 & 5.011 & .000 & 15.16250 & .98917 \\
\hline \multirow{2}{*}{$\begin{array}{l}\text { Third- } \\
\text { party } \\
\text { funds }\end{array}$} & .288 & .611 & 7.097 & 6 & .000 & 29259.500 & 4122.992 \\
\hline & & & 7.097 & 5.321 & .001 & 29259.500 & 4122.992 \\
\hline \multirow{2}{*}{ Financing } & .004 & .950 & 8.353 & 6 & .000 & 26707.250 & 3197.280 \\
\hline & & & 8.353 & 5.990 & .000 & 26707.250 & 3197.280 \\
\hline \multirow{2}{*}{ ROA } & 2.096 & .198 & -23.599 & 6 & .000 & -1.17750 & .04990 \\
\hline & & & -23.599 & 4.262 & .000 & -1.17750 & .04990 \\
\hline \multirow{2}{*}{ ROE } & 1.382 & .284 & -11.822 & 6 & .000 & -7.22500 & .61115 \\
\hline & & & -11.822 & 5.560 & .000 & -7.22500 & .61115 \\
\hline
\end{tabular}

Source: Financial report of Bank Muamalat and BNI Syariah, 2016

From table 1.3 above, it can be interpreted that the five indicators of marketing performance of Islamic banks studied, namely Market Share, Third Party Funds (DPK), Financing, ROA and ROE have Sig value. (2-tailed) by 0.000 , less than $5 \%$ or 0.05 . Thus, according to the basis of decision making in the Independent Sample $t$ Test, it can be concluded that there is a difference between marketing performance of Bank Muamalat and Marketing Performance of BNI Syariah. The difference between the marketing performance of both Islamic banks will be the authors describe below. 
Table 4

Marketing Performance of Bank Muamalat dan BNI Syariah

\begin{tabular}{|c|l|c|c|c|c|c|c|}
\hline Indicators & Bank & $\mathbf{2 0 1 2}$ & $\mathbf{2 0 1 3}$ & $\mathbf{2 0 1 4}$ & $\mathbf{2 0 1 5}$ & $\mathbf{2 0 1 6}$ & Mean \\
\hline \multirow{2}{*}{ Market share* } & $\begin{array}{l}\text { Bank } \\
\text { Muamalat }\end{array}$ & 22,70 & 22,18 & 22,93 & 19,30 & 15,65 & $\mathbf{2 0 , 5 5}$ \\
\cline { 2 - 7 } & $\begin{array}{l}\text { BNI } \\
\text { Syariah }\end{array}$ & 5,46 & 6,07 & 7,16 & 7,77 & 7,94 & $\mathbf{6 , 8 8}$ \\
\hline \multirow{3}{*}{$\begin{array}{l}\text { Third-party } \\
\text { funds** }\end{array}$} & $\begin{array}{l}\text { Bank } \\
\text { Muamalat }\end{array}$ & 34.903 & 41.789 & 51.206 & 45.077 & 41.920 & $\mathbf{4 2 . 9 7 9}$ \\
\cline { 2 - 8 } & $\begin{array}{l}\text { BNI } \\
\text { Syariah }\end{array}$ & 8.947 & 11.422 & 16.246 & 19.322 & 24.233 & $\mathbf{1 6 . 0 3 4}$ \\
\hline \multirow{3}{*}{ ROA* } & $\begin{array}{l}\text { Bank } \\
\text { Muamalat }\end{array}$ & 32.861 & 41.801 & 43.115 & 40.734 & 40.010 & $\mathbf{3 9 . 7 0 4}$ \\
\cline { 2 - 8 } & $\begin{array}{l}\text { BNI } \\
\text { Syariah }\end{array}$ & 7.631 & 11.242 & 15.044 & 17.765 & 20.494 & $\mathbf{1 4 . 4 3 5}$ \\
\hline $\begin{array}{l}\text { Bank } \\
\text { Muamalat }\end{array}$ & 0,20 & 0,27 & 0,17 & 0,20 & 0,22 & $\mathbf{0 , 2 1}$ \\
\cline { 2 - 7 } & $\begin{array}{l}\text { BNI } \\
\text { Syariah }\end{array}$ & 1,48 & 1,37 & 1,27 & 1,43 & 1,44 & $\mathbf{1 , 3 9}$ \\
\hline ROE* & $\begin{array}{l}\text { Bank } \\
\text { Muamalat }\end{array}$ & 3,43 & 3,87 & 2,20 & 2,78 & 3,00 & $\mathbf{3 , 0 5}$ \\
\cline { 2 - 7 } & $\begin{array}{l}\text { BNI } \\
\text { Syariah }\end{array}$ & 9,31 & 9,65 & 10,83 & 11,39 & 11,94 & $\mathbf{1 0 , 6 2}$ \\
\hline
\end{tabular}

Source: Financial report of Bank Muamalat and BNI Syariah, 2012-2016

$*$ : in percent, ${ }^{* *}:$ in billion rupiah

Table 4 above shows a comparison of marketing performance of Bank Muamalat and BNI Syariah from 2012 to 2016. There are two aspects that used to measure the marketing performance of both Islamic banks, namely the aspects of market performance and financial performance. Market performance is measured by market share, third party funds, and financing. While financial performance is measured by ROA and ROE.

During the period 2012 to 2016, the average market share achieved by Bank Muamalat is $20.55 \%$. This figure is greater when compared with the acquisition of BNI Syariah market share with an average of $6.88 \%$. It is understandable that Bank Muamalat was the first Islamic bank in Indonesia that was born in 1992, while BNI Syariah started its operations in 2010 as Islamic Commercial Bank (BUS). However, from the aspect of 
the development of its market share, Bank Muamalat tends to experience a downward trend of growth. Unlike the BNI Syariah which experienced a growing trend of market share growth.

In the same period, the average third party fund managed by Bank Muamalat amounted to Rp 42.97 trillion, while the average third party fund managed by BNI Syariah amounted to Rp 16.03 trillion. In terms of DPK achievement, the data held by Bank Muamalat looks higher than BNI Syariah. The main factor is the market share that has been achieved by Bank Muamalat bigger than the market share of BNI Syariah. Likewise with the wider service network of Bank Muamalat compared with BNI Syariah. Although the performance of Bank Muamalat's DPK is higher than that of BNI Syariah, the growth rate of BNI Syariah DPK looks better compared to Bank Muamalat. For 5 years, Bank Muamalat's DPK only grew by $16.73 \%$, while BNI Syariah deposits experienced significant growth of $63.07 \%$.

According to the financing disbursed, Bank Muamalat has managed to disburse financing with an average of Rp 39.70 trillion, while the average distribution of BNI Syariah financing in the same period amounted to Rp 14.43 trillion. The financing distribution of Bank Muamalat also looks bigger compared to the financing channeled by BNI Syariah. This is because the achievement of Third Party Funds (DPK) of Bank Muamalat is higher compared to the achievement of BNI Syariah DPK, so Bank Muamalat has more opportunity to channel more financing compared to BNI Syariah.

However, the high rate of disbursement of financing by Bank Muamalat was not accompanied by good asset quality management, thus indirectly affect its profitability (Wibowo and Syaichu, 2013). This can be seen from the high number of bad debts that occurred in Bank Muamalat customers during the period. In 2012, Bank Muamalat's gross margin (NPF Gross) reached $5.77 \%$, and this number continues to increase until 2015 reaches 7.11\% (Annual Report Bank Muamalat, 2016). Meanwhile, BNI Syariah is in a safe position in terms of financing control problematic. In fact, the NPF Gross BNI Syariah tend to decrease trend. In 2012, NPF Gross BNI Syariah touched 3.62\% and in 2015 BNI Syariah was able to reduce NPF Gross to $2.53 \%$. This means that BNI Syariah management can keep their Gross NPF figure below the safe limit set by Bank Indonesia, which is 5\% (Financial Report of BNI Syariah, 2016). 
In terms of financial performance, the average ROA of Bank Muamalat from 2012 to 2016 is $0.21 \%$. The rate of return on assets in the last 5 years tends to decline. While the average BNI Syariah ROA of the same period of $1.39 \%$. Compared to Bank Muamalat, the achievement of BNI Syariah ROA from 2012 to 2016 has an upward trend. The ability of BNI Syariah to generate profit better than Bank Muamalat. In accordance with PBI no. 9/1 / PBI / 2007 Concerning the Rating System of Commercial Banks Based on Sharia Principles, the financial condition of Bank Muamalat is categorized under adverse circumstances, seeing the average ROA achievement below BI health standard of $0.21 \%$. While the financial condition of BNI Syariah in good condition because the achievement of average ROA above BI health standard, that is equal to $1,39 \%$.

Meanwhile, the average ROE of Bank Muamalat during the period 2012 to 2016 amounted to 3.05\%. While BNI Syariah recorded average ROE in the same period of $10.62 \%$. Compared to Bank Muamalat, the performance of BNI Syariah management in generating net profit looks better. This is based on the trend of BNI Syariah ROE increase, where in 2016 ROE BNI Syariah was recorded at $11.94 \%$, significantly increased compared to ROE in 2012 which was recorded at $9.31 \%$. In contrast, Bank Muamalat actually experienced a downward trend in ROE from $3.43 \%$ in 2012 to $3.00 \%$ in 2016.

\section{The influence of corporate culture on marketing performance}

After identifying the corporate culture typology and marketing performance of Bank Muamalat and BNI Syariah, the authors conducted a simple regression test to determine the influence of corporate culture on marketing performance.

Table 5

Determinant Coefficient

\begin{tabular}{|c|c|c|c|c|}
\hline \multicolumn{5}{|c|}{ Model Summary } \\
\hline Model & $\mathrm{R}$ & R Square & Adjusted R Square & $\begin{array}{c}\text { Std. Error } \\
\text { of the } \\
\text { Estimate }\end{array}$ \\
\hline 1 & $.813^{\mathrm{a}}$ & .661 & .655 & 1.196 \\
\hline a. Predictors: (Constant), Corporate Culture & \\
\hline
\end{tabular}


Table 5 is the result of data using SPPS which shows Determinant Coefficient test $\left(\mathrm{R}^{2}\right)$. From the table, it can be seen that the value of Adjusted $\mathrm{R}^{2}$ is 0.661 . This means that $66 \%$ of Marketing Performance variables can be explained by the variables of Corporate Culture. While the rest $(100 \%-66.1 \%=$ $33.9 \%$ ) is explained by other factors outside the model (Ghozali, 2011). After knowing the value of the ability of corporate culture variables in explaining marketing performance variables, the next step is to test the relationship between the two variables. The test equipment used is Statistical Test F.

Table 6

Uji Signifikansi Simultan (Uji Statistik F)

\begin{tabular}{|l|l|c|c|c|c|c|}
\hline \multicolumn{7}{|c|}{ ANOVA $^{\mathrm{a}}$} \\
\hline \multicolumn{2}{|c|}{ Model } & $\begin{array}{c}\text { Sum of } \\
\text { Squares }\end{array}$ & Df & $\begin{array}{c}\text { Mean } \\
\text { Square }\end{array}$ & F & Sig. \\
\hline \multirow{3}{*}{1} & Regression & 161.984 & 1 & 161.984 & 113.194 & $.000^{\mathrm{b}}$ \\
\cline { 2 - 7 } & Residual & 82.999 & 58 & 1.431 & & \\
\cline { 2 - 7 } & Total & 244.983 & 59 & & & \\
\hline \multicolumn{2}{|l}{$\begin{array}{l}\text { a. Dependent Variable: Marketing Performance } \\
\text { b. Predictors: (Constant), Corporate Culture }\end{array}$} \\
\hline
\end{tabular}

Table 6 above shows the results of $F$ statistical tests From the table above can be seen that the value of $F$ of 113.194 with significance 0.000 . Since the value of $F$ arithmetic is greater than $\mathrm{F}$ table (greater than 4) and the value of significance is also smaller than 0.05 , it can be concluded that the variables of corporate culture have an influence on marketing performance variables (Rankuti, 2013). After knowing that corporate culture variable have influence to marketing performance, hence final step of this simple linear regression test is to test the significance of corporate culture influence to marketing performance.

Table 7

Regression Test

\begin{tabular}{|c|c|c|c|c|c|}
\hline \multicolumn{7}{|c|}{ Coefficients $^{\mathbf{a}}$} \\
\hline \multirow{2}{*}{$\begin{array}{c}\text { Model } \\
\text { B }\end{array}$} & \multicolumn{2}{|c|}{$\begin{array}{c}\text { Unstandardized } \\
\text { Coefficients }\end{array}$} & $\begin{array}{c}\text { Standardized } \\
\text { Coefficients }\end{array}$ & & Sig. \\
\cline { 2 - 3 } & $\begin{array}{c}\text { Std. } \\
\text { Error }\end{array}$ & Beta & & & \\
\hline
\end{tabular}




\begin{tabular}{|c|c|c|c|c|c|c|}
\hline \multirow{3}{*}{1} & (Constant) & 2.491 & 1.605 & & 1.552 & .126 \\
\cline { 2 - 7 } & $\begin{array}{c}\text { Budaya } \\
\text { Perusahaan }\end{array}$ & .189 & .018 & .813 & 10.639 & .000 \\
\hline \multirow{2}{*}{ a. Den } & & & & & \\
\hline
\end{tabular}

a. Dependent Variable: Kinerja Pemasaran

From table 7 can be seen the results of simple linear regression test that test the significance of the influence of independent variables on the dependent variable. Corporate culture variables appear to have a significance value of 0.000 , smaller when compared with the level of significance 0.05 . The result of statistical analysis also shows the value of positive constant of independent variable and dependent variable. That is, if the value of independent variables or corporate culture rose, then the value of the dependent variable or marketing performance also increased. Based on the hypothesis that has been proposed and the results of data analysis, it can be concluded that corporate culture has a positive influence on marketing performance. Looking at the results of $\mathrm{F}$ statistical analysis and statistical test $t$ above, the corporate culture of Bank Muamalat and BNI Syariah simultaneously and partially have a positive and significant impact on marketing performance. That is, in this study $\mathrm{H} 0$ rejected and $\mathrm{H} 1$ accepted.

\section{E. CONCLUTION}

After conducting a thorough analysis of existing data through mixed methods, this study proves that corporate culture that accommodates Islamic teachings (values, ethics and Islamic symbols) contributes positively to its marketing performance. The corporate culture of both Islamic Bank dominated by clan type of culture, which is characterized by close interpersonal relationships between individuals within the company, teamwork and employee participation in the preparation and implementation of business strategy, as well as the honesty and loyalty that adhesive the relationship.

From the growth trend during the period of 2012 to 2016, marketing performance data of BNI Syariah looks higher compared to marketing performance of Bank Muamalat. In terms of market performance of BNI Syariah, market share, third party funds (DPK), and financing disbursement rate always increase from year to year during the period compared to Bank Muamalat. From the aspect of its financial performance, profitability data of BNI Syariah is also higher compared to Bank Muamalat. 
From the results of statistical tests using the regression method, it can be concluded that the independent variables in this study have a positive and significant effect on the dependent variable. That is, the corporate culture of Bank Muamalat and BNI Syariah with its Islamic characteristics provide a positive and significant impact on marketing performance. This further strengthens the views of management experts such as John P. Kotter, Manzoor Ahmed, Muhammad Khalilur Rahman, Norhayati Zakaria, MD. Mahabub Alom and others who stated that corporate culture can have an effect on marketing.

This study uses only two variables, namely corporate culture and marketing performance. The object in this study also only comparing two Islamic banks, namely Bank Muamalat and BNI Syariah. Further research is expected to involve more variables that can explain marketing performance such as capital, innovation, and economic fundamentals of the country and multiply the object of the study in order to obtain more comprehensive results. Given the complexity of corporate culture studies, subsequent studies can also use other corporate culture theories, due to the limitations of Cameron and Quinn's organizational culture theory which has only 6 cultural dimensions. The more cultural dimensions being studied, the broader and clearer the image of the company's culture. 


\section{BIBLIOGRAPHY}

Acar, Adam, Jeevan Madhusanka Premasara dan Joshua Smith Glen (2011). An Exploratory Study about Culture and Marketing Strategy. Asian Journal of Business Research. 105-116.

Ahmad, Khaliq dan Ogunsola OK (2011). An Empirical Assessment of Islamic Leadership Principles. International Journal of Commerce and Management vol. 21, no. 3. 291318.

Ahmad, Naveed, Nadeem Iqbal dan Komal Javed (2014). Impact of Islamic Fashion Marketing on Islamic Marketing; A Case Study of Pakistani Women's. Kuwait Chapter of Arabian Journal of Business and Management Review vol. 3, no. 5. 66-72.

Ahmed, Manzoor, Shafi Ullah dan Aftab Alam (2014). Importance of Culture in Success of International Marketing. European Academic Research. 3802-3816.

Alom, Md. Mahabub dan Md. Shariful Haque (2011). Marketing: An Islamic Perspective. World Journal of Social Sciences vol. 1 , no. 3. 71-81.

Antunes, Isabel (2013). The Impact of National Cultures on International Marketing Strategy. The International Journal of Management vol. 2, no. 3. 38-45.

Astami, Wulan Sari (2013). Analisis Pengukuran Kinerja Pemasaran Melalui Financial Metrics: Studi Kasus Untuk Produk CN-235 di PT. Dirgantara Indonesia. Jurnal Ilmu Manajemen E Bisnis vol. 04, no. 01. 1-14.

Bakri, Adzan Noor (2015). Pemasaran Berbasis Spiritual: Studi Tentang Prediktor Determinan Sustainabilitas Bank Syariah. Jakarta, Pascasarjana UIN Syarif Hidayatullah.

Beikzad, Jafar, Ali Jahedi Chaharborj dan Saeid Ghorbannajed Maleki (2012). The Effect of Islamic Values on Relational Marketing Basics. Management Science Latter 2. 797-804. 
Berson, Yair, Shaul Oreg dan Taly Dvir (2008). CEO Values, Organizational Culture, and Firm Outcomes. Journal of Organizational Behavior vol. 29, no. 5. 615-633.

Borden, Neil H (1984). The Concept of the Marketing Mix. Journal of Advertising Research. 7-12.

Cameron, Kim S. dan Robert E. Quinn (2006). Diagnosing and Changing Organizational Culture Based on The Competiting Values Framework. San Francisco, Jossey-Bass.

Choudhury, Masudul Alam dan Mohammad Ziaul Hoque (2006). Corporate governance in Islamic perspective. Corporate Governance: The international journal of business in society vol. 6, no: 2. 116-128.

Creswell, John W (2009). Research Design: Qualitative, Quantitative, and Mixed Methods Approaches. USA: Sage Publications.

Deshpand Luna é, Rohit, John U. Farley dan Frederick E. Webster Jr (1993). Corporate Culture, Customer Orientation, and Innovativeness in Japanese Firms: A Quadrad Analysis. Journal of Marketing 57, no. 1. 23-37.

Deshpande,RohitdanFrederickE.Webster(1989).Organizational Culture and Marketing: Defining the Research Agenda. Journal of Marketing 53, no. 1. 3-15.

Fauzia, Ika Yunia (2013). Etika Bisnis Dalam Islam. Jakarta, Kencana Prenadamedia Grup.

Galanou, Aikaterini dan Dalia Abdelrahman Farrag (2015). Towards the distinctive Islamic mode of leadership in business. Journal of Management Development vol. 34, no. 8. 882-900.

Ghozali, Imam (2011). Aplikasi Analisis Multivariate dengan Program IBM SPSS 19. Semarang, Badan Penerbit Undip.

Goi, Chai Lee (2009). A Review of Marketing Mix: 4Ps or More?. International Journal of Marketing Stuudies. 2-15. 
Hassan, Abul, Abdelkader Chachi dan Salma Abdul Latiff (2008). Islamic Marketing Ethics and Its Impact on Customer Satisfaction in the Islamic Banking Industry. JKAU: Islamic Econ vol. 21. 27-46.

Homburg, Christian dan Christian Pflesser (2000). A MultipleLayer Model of Market-Oriented Organizational Culture: Measurement Issues and Performance Outcomes. Journal of Marketing Research vol. 37, no. 4. 449-62.

Kamarulzaman, Yusniza dan Azian Madun (2013). Marketing Islamic Banking Products: Malaysian Perspective. Business Strategy Series vol. 14, no. 2/3. 60-66.

Kartajaya, Hermawan dan Muhammad Syakir Sula (2006). Shariah Marketing. Bandung, Mizan.

Kashif, Muhammad, Anna Zarkada, Ramayah Thurasamy (2017). The moderating effect of religiosity on ethical behavioural intentions: An application of the extended theory of planned behaviour to Pakistani bank employees. Personnel Review vol. 46, no. 2. 429-448.

Kotler, Philip dan Amstrong G (2012). Prinsiples of Marketing. New Jersey, Pearson Prentie-Hall, $14^{\text {th }}$ ed.

Kotler, Philip, Hermawan Kartajaya dan Iwan Setiawa (2010). Marketing 3.0. Canada, John Wiley \& Sons, Inc..

Kotter, John P. dan James L. Heskett (1997). Corporate Culture and Performance. Jakarta, Prenhalindo.

Kunaifi, Aang (2016). Manajemen Pemasaran Syari'ah Pendekatan Human Spirit; Konsep, Etika, Strategi, dan Implementasi. Yogyakarta, Maghza Pustaka.

Luna, David dan Susan Forquer Gupta (2001). An Integrative Framework For Cross-Cultural Consumer Behavior. International Marketing Review vol. 18, no. 1. 45-69.

Marieke de Mooij dan Geert Hofstede (2011). Cross-Cultural Consumer Behavior: A Review of Research Findings. Journal of International Consumer Marketing, vol. 23. 181-19. 
Naser, Abbas dan Ezhar Tamam (2012). Impact of Islamic Religious Symbol in Producing Favorable Attitude Toward Advertisement. The Public Administration and Social Policies Review vol. 4, no. 18. 61-77.

Rahman, Muhammad Khalilur, Abdullah-Al-Mamun, Abdul Highe Khan dan Md. Abdul Jalil (2014). Ethical Implications of Sales Promotion in Malaysia: Islamic Perspective. Journal of Business Law and Ethics vol. 2, no. 1. 13-27.

Rangkuti, Freddy (2013). Riset Pemasaran. Jakarta, Gramedia Pustaka Utama.

Schein, Edgar H (2004). Organizational Culture and Leadership. San Francisco, Jossey Bass.

Simberova, Iveta (2009). Corporate Culture - as a Barrier of Market Orientation Implementation. Economics and Management 14. 513-21.

Slater, Stanley F., Eric M. Olson dan Carol Finnegan (2011). Business Strategy, Marketing Organization Culture, and Performance. Marketing Letters vol. 22, no. 3. 227-242.

Solcansky, Marek, Lucie Sychrova dan František Milichovský (2011). Marketing Effectiveness by Way of Metrics. Economic and Management 16. 1323-1328.

Sutrisno, Edy (2010). Budaya Organisasi. Jakarta, Kencana.

Usman, Hardius, Prijono Tjiptoherijanto, Tengku Ezni Balqiah, I Gusti Ngurah Agung (2017). The role of religious norms, trust, importance of attributes, and information sources in the relationship between religiosity and selection of the Islamic bank. Journal of Islamic Marketing, Vol. 8, no. 2.

Wibowo, Edhi Satriyo dan Muhammad Syaichu (2013). Analisis Pengaruh Suku Bunga, Inflasi, CAR, BOPO, NPF terhadap Profitabilitas Bank Syariah. Journal of Mangement vol. 2, no. 2 (2013): 1-10.

www.ojk.go.id 
Yu, Tianyuan dan Nengquan Wu (2009). A Review of Study On the Competing Values Framework. International Journal of Business and Management vol. 4, no. 7 (2009): 37-42.

Yusanto, Muhammad Ismail. (2002). Menggagas Bisnis Islam. Jakarta, Gema Insani Press. 